\title{
First report of Gibellulopsis nigrescens on peppermint in Germany
}

\author{
Elias Alisaac ${ }^{1}\left[\right.$ [D $\cdot$ Monika Götz ${ }^{1}$
}

Received: 27 September 2021 / Accepted: 4 October 2021 / Published online: 13 October 2021

(c) The Author(s) 2021

\begin{abstract}
Peppermint is an important medicinal plant, and it is known for its essential oils and phenolic acids. Verticillium wilt is a vascular disease resulted from several Verticillium spp. causing significant economic losses in peppermint cultivation. In this study, the fungus Gibellulopsis nigrescens (syn. Verticillium nigrescens) was isolated from symptomless peppermint plants during the regular control of Verticillium wilt on peppermint in Germany. A pure fungal culture was prepared, and fungal DNA was extracted. Ribosomal internal transcribed spacer (ITS), beta-tubulin (TUB), and translation elongation factor 1- $\alpha$ (TEF1- $\alpha$ ) were amplified, sequenced, and deposited in the GenBank. These sequences are located within the Gibellulopsis nigrescens cluster. Koch's postulate was fulfilled, and the fungus was re-isolated from the inoculated plants. Up to our knowledge, this is the first report of Gibellulopsis nigrescens on peppermint in Germany.
\end{abstract}

Keywords Wilt $\cdot$ Aromatic plant $\cdot$ Medicinal plants $\cdot$ Essential oils $\cdot$ Menthol $\cdot$ Menthone $\cdot$ Therapeutic uses

\section{Introduction}

Peppermint (Mentha x piperita) is an important medicinal plant in Germany that is known for its essential oils, i.e., menthol and menthone in addition to the phenolic acids. It has therapeutic uses against the common cold and irritable bowel syndrome (Honermeier et al. 2013). Verticillium wilt is considered one of the biggest challenges in peppermint cultivation, and this is because of the economic losses resulting from this disease. It is caused by several Verticillium species mainly $V$. dahliae. The main problem of this fungus is that it can persist as microsclerotia in the soil for more than ten years (Dung 2020). Gibellulopsis nigrescens (syn. Verticillium nigrescens) is a weak pathogen involved in Verticillium wilt on peppermint (Melouk and Horner 1974). In their study, Melouk and Horner (1974) reported that peppermint plants showed typical wilt symptoms 4-5 weeks after inoculation; however, 6-8 weeks after inoculation, these symptoms disappeared and the plants recovered and grew normally. This suggests that this pathogen does not cause significant losses in peppermint production under normal

Elias Alisaac

elias.alisaac@julius-kuehn.de

1 Institute for Plant Protection in Horticulture and Forests, Julius-Kühn-Institute, Messeweg 11-12, 38104 Braunschweig, Germany field conditions. However, under another biotic or/and abiotic stresses, the pathogen might be involved in yield losses.

In this paper, symptomless peppermint plants and stolons were received from professionally cultivated fields for regular control of $V$. dahliae infection in June and October 2020. Verticillium-like fungus was recovered with a high ratio from the samples; however, the molecular investigations indicated that this fungus was not $V$. dahiae but $G$. nigrescens formally known as $V$. nigrescens. This work was done to fulfill Koch's postulate and verify whether $G$. nigrescens is able to infect peppermint plants after artificial inoculation under greenhouse conditions.

\section{Materials and methods}

\section{Collection and maintenance of the Gibellulopsis nigrescens isolate}

Peppermint head cuttings and stolons cv. 'Multimentha' were received from professionally cultivated fields in Thuringia in June and October 2020. The plant stems and stolons were cleaned, surface-sterilized in $1 \% \mathrm{NaOCl}$ for $2 \mathrm{~min}$, washed in distilled sterilized water for $2 \mathrm{~min}$ twice, and dried on sterile filter paper under the laminar flow hood. After drying, the terminals of the plant tissue were discarded and pieces of the plant tissue were transferred 
to potato dextrose agar (PDA) and synthetic nutrient agar (SNA) and incubated at $25{ }^{\circ} \mathrm{C}$ for 5 days under UV light. Verticillium-like or similar fungi could be observed with a very high ratio (>90\%) of the tested plants. Single spore isolates were prepared per sampling time, and one isolate obtained from head cuttings in June was used for further investigations.

Fungal DNA was extracted using DNeasy® Plant Mini Kit (QIAGEN®, Germany) following the manufacturers' recommendations. Ribosomal internal transcribed spacer (ITS), beta-tubulin (TUB), and translation elongation factor 1- $\alpha$ (TEF1- $\alpha$ ) were amplified and sequenced using the primer pairs ITS1/ITS4, VTubF2/VTubR, and EF728/ EF2, respectively (Inderbitzin et al. 2011; O'Donnell et al. 1998; White et al. 1990). Amplicons were purified using the MSB Spin PCRapace Kit (Stratec Biomedical AG) and sequenced for each primer pair twice in each direction (LGC Genomics GmbH). Contigs were generated and edited using CLC Main Workbench 8.1 (Qiagen) following the EPPO recommendations for sequence analysis (OEPP/ EPPO 2021). The consensus sequences were submitted to the GenBank under the accession numbers MZ363932, MZ384017, and MZ384018 for ITS, TUB, and TEF1- $\alpha$, respectively.

To fulfill Koch's postulates, mycelium was cultured in potato dextrose broth (PDB) for three weeks, while spore suspension of $1 \times 10^{6}$ conidia $\mathrm{mL}^{-1}$ was produced by incubating $5 \mathrm{ml}$ of mycelium suspension on low-strength potato dextrose agar (LSPDA) for 1 week and collecting the spores in sterilized water (Alisaac et al. 2018). Two sets of peppermint cv. 'Multimentha' cuttings (20 per each set) were rooted for 3 weeks in water or clay substrate (Klasmann-Deilmann GmbH, Germany). The first set was inoculated by incubating the roots $(n=5)$ in a spore suspension or a mycelium suspension for $24 \mathrm{~h}$. The same number of plants were sunk in water or PDB as control treatments. Afterward, the plants were planted in clay substrate in pots with $10 \mathrm{~cm}$ diameter. The second set was inoculated by adding $10 \mathrm{ml}$ of spore suspension or mycelium suspension to the clay substrate $(n=5)$. The same amount of water or PDB was added to the same number of plants as control treatments. Both sets were kept for 5 weeks under greenhouse conditions (temperature of $25 / 20{ }^{\circ} \mathrm{C} 16 / 8 \mathrm{~h}$ day/night, 50\% RH, and natural light). Plants were monitored for symptoms regularly. For fungal re-isolation, plant roots and stem bases were surface-sterilized as described before and incubated on SNA at $25^{\circ} \mathrm{C}$ for 2 weeks under UV light. To check the sterilization efficiency, the sterilized roots and stem bases were pressed on PDA before incubating them on SNA. Out growing mycelia were isolated and inspected microscopically for morphological structures.

\section{Results}

The young pure colonies showed white aerial mycelium with rounded conidia on PDA. With aging, the colonies showed gray to black color. The conidia were hyaline, smoothwalled, elongate ellipsoidal with $4.76 \mu \mathrm{m}(3.49-7.1 \mu \mathrm{m})$ length and $2.68 \mu \mathrm{m}(2.1-3.58 \mu \mathrm{m})$ width (Fig. 1).

The sequences of ITS, TUB, and TEF1- $\alpha$ showed similarity to Gibellulopsis nigrescens (syn. Verticillium nigrescens) with 100, 98.10, and 100\% identity, respectively. The comparison with GenBank sequences showed that the sequences of this isolate are located within the Gibellulopsis nigrescens cluster.

No wilting symptoms were observed on the plants during the observation period. In addition, the roots and the stem bases did not show any discoloration symptoms. The results showed that the fungus was not present in control plants, while it was present in $100 \%$ of the roots and the stems of the inoculated plants.

\section{Discussion}

Generally, $V$. dahliae is the main causal agent of wilt symptoms and yield losses on peppermint; however, other Verticillium spp. can be involved in wilt symptoms and yield losses (Dung 2020). The severity of wilt symptoms on peppermint is related to the cultivars and the causal agent of the diseases. For example, G. nigrescens was previously reported as a causal agent of Verticillium wilt on peppermint in the USA (Melouk and Horner 1974). This pathogen caused slight and temporal wilt symptoms, e.g. stunting and twisting the top leaves; however, the infected plants

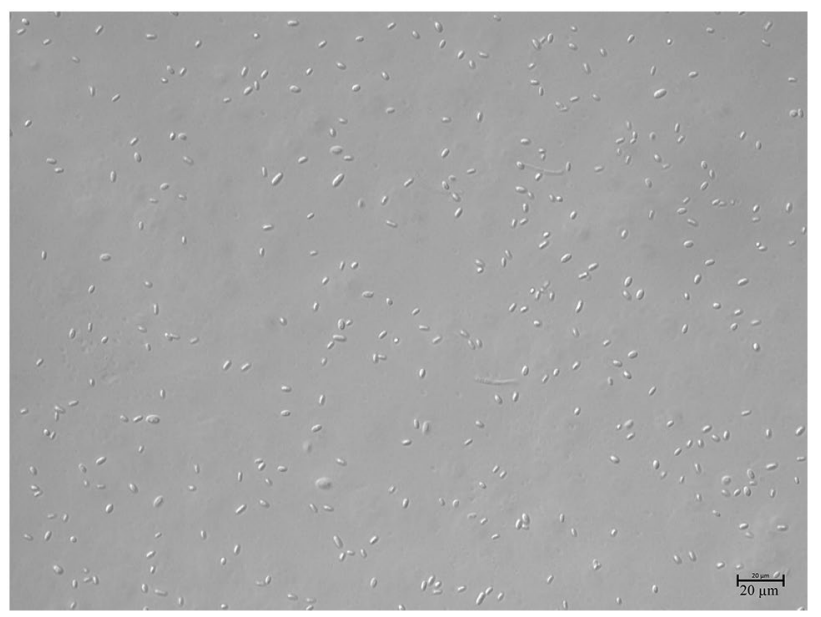

Fig. 1 The conidia of Gibellulopsis nigrescens re-isolated from peppermint plants after fulfilling Koch's postulate. $\mathrm{Bar}=20 \mu \mathrm{m}$ 
recovered after two weeks of these symptoms. The recovery of the plants could be attributed to the fast growth of peppermint stolons and roots that can compensate for the deficiency of water supply resulting from the infection.

In the current study, G. nigrescens was found asymptomatically with a high infection ratio on peppermint plants in Germany. After an artificial inoculation under greenhouse conditions, the fungus was re-isolated from all inoculated plants, although it did not cause any wilt symptoms on peppermint. This could be attributed to two reasons: either the fungal isolate is not virulent to cause visible symptoms on peppermint or the cultivar 'Multimentha' used in the current study is resistant to $G$. nigrescens.

G. nigrescens is considered as a weak pathogen on peppermint; however, under other biotic and/or abiotic stresses, it might become a problem causing wilt symptoms and yield losses. Up to our knowledge, this is the first report of this pathogen on peppermint in Germany.

Funding Open Access funding enabled and organized by Projekt DEAL.

\section{Declarations}

Conflicts of interest The authors declare that they have no conflict of interest.

Consent for publication The manuscript has been fully approved in the Publication Approval workflow at the Julius-Kühn-Institute.

Open Access This article is licensed under a Creative Commons Attribution 4.0 International License, which permits use, sharing, adaptation, distribution and reproduction in any medium or format, as long as you give appropriate credit to the original author(s) and the source, provide a link to the Creative Commons licence, and indicate if changes were made. The images or other third party material in this article are included in the article's Creative Commons licence, unless indicated otherwise in a credit line to the material. If material is not included in the article's Creative Commons licence and your intended use is not permitted by statutory regulation or exceeds the permitted use, you will need to obtain permission directly from the copyright holder. To view a copy of this licence, visit http://creativecommons.org/licenses/by/4.0/.

\section{References}

Alisaac E, Behmann J, Kuska MT, Dehne H-W, Mahlein A-K (2018) Hyperspectral quantification of wheat resistance to Fusarium head blight: comparison of two Fusarium species. Eur J Plant Pathol 152:869-884. https://doi.org/10.1007/s10658-018-1505-9

Dung JKS (2020) Verticillium wilt of mint in the United States of America. Plants (Basel) 9. https://doi.org/10.3390/plants9111602

Honermeier B, Sajid A, Leschhorn B, Mahmood A, Ijaz M, Russo M, Shafiee-Hajiabad M, Ullah H, Zeller S (2013) Cultivation of medicinal and spice plants in Germany - a review. Int J Agric Biol 15:1379-1388. https://doi.org/10.1046/j.0013-0427.2003.00027.x

Inderbitzin P, Davis RM, Bostock RM, Subbarao KV (2011) The ascomycete Verticillium longisporum is a hybrid and a plant pathogen with an expanded host range. PLoS ONE 6:e18260. https://doi. org/10.1371/journal.pone. 0018260

Melouk HA, Horner CE (1974) Verticillium nigrescens from peppermint. Phytopathology 64:1267-1268

O’Donnell K, Kistler HC, Cigelnik E, Ploetz RC (1998) Multiple evolutionary origins of the fungus causing Panama disease of banana: concordant evidence from nuclear and mitochondrial gene genealogies. Proc Natl Acad Sci USA 95:2044-2049. https://doi.org/ 10.1073/pnas.95.5.2044

OEPP, EPPO, (2021) PM 7/129 (2) DNA barcoding as an identification tool for a number of regulated pests. EPPO Bull 51:100-143. https://doi.org/10.1111/epp.12724

White TJ, Bruns T, Lee S, Taylor J (1990) Amplification and direct sequencing of fungal ribosomal RNA genes for phylogenetics. In: Innis MA, Gelfand DD, Sninsky JJ, White TJ (eds) PCR Protocols: a guide to methods and applications. Academic Press Inc, New York, pp 315-322

Publisher's Note Springer Nature remains neutral with regard to jurisdictional claims in published maps and institutional affiliations. 